\title{
Common Waterborne Diseases in Marginalized areas: a Case Study: Al Shuka Area in Gaza Strip-Palestine
}

\author{
Ghada Al Khatib ${ }^{1,2}$, Mazen Hamada ${ }^{3}$, Amal Sarsour ${ }^{4,5}$ \\ ${ }^{1}$ Environmental Awareness Department, Holest Cultural Center at Gaza Municipality \\ ${ }^{2}$ Institute of Water and Environment al Azhar University Gaza Palestine \\ ${ }^{3}$ Chemistry Department, Faculty of Science at Al Azhar University Gaza-Palestine \\ ${ }^{4}$ Earth and Human Center for Research and Studies, Al Shifa Street, Alkarmel Building, Gaza strip, Palestine \\ ${ }^{5}$ School of Public Health, Al Quds University, Gaza Strip, Palestine
}

\begin{abstract}
Lack of sustainability of water supply and sanitation services are always considered as major issue in developing countries that accounts for high prevalence of water borne diseases. The aim of this study is to identify the common water borne diseases among people of Al Shuka rural community in the Gaza Strip - Palestine. Cross-sectional study was conducted; the researcher utilized an oral-administrated questionnaire. A simple random sample technique was conducted to collect data. Based on the study results it is concluded that about $34.6 \%$ of the study sample have suffered from diarrhea. While $54.8 \%$ of the study suffered from other waterborne disease which include dermal disease (skin), colic disease (stomach pain) and eyes disease during last two weeks before filling the questionnaire. Accordingly, safe and clean water supply should be ensured in order to cover people needs and protect their health. Also, conducting public awareness campaigns and behaviour change towards improving the surrounded environment, personal hygiene, cleanliness and sanitary programs should be ensured mainly in rural and vulnerable area of the Gaza Strip.
\end{abstract}

Keywords: Al Shuka area, common, water borne diseases, Gaza Strip, Palestine

\section{Introduction}

Drinking water is considered as a major source of microbial pathogens in developing regions, although poor sanitation and food sources are integral to enteric pathogen exposure (1) Moreover, the failure to provide people with safe drinking water and basic sanitation services is estimated to contribute to the deaths of approximately 3.57 million people annually from water-related diseases, around 6 percent of all deaths worldwide $(2,3)$. The World Health Organization (WHO), estimates that more than 780 million people lack access to an improved source of drinking water, while some 2.5 billion have no access to improved sanitation (4).

Biological contamination of drinking water through Fecal and Total coliform have been found in numerous wells in the Gaza Strip, most likely caused by inefficient sewage systems and improper disposal of animal waste (5). Due to the contamination, the municipal water from the tap is not suitable for drinking or cooking, which means people have to purchase water from private vendors despite being connected to a water network. Many residents in Gaza cannot afford to continuously buy extra water due to the high unemployment and poverty rates, and therefore obliged to drinking the contaminated water $(6,7)$. In many cases, the quality of water from private vendors has also been reported unsafe because the PWA does not have the capacity to control and regulate all private vendors $(8,9)$.
Commonly, inadequate water supplies, such as insufficient or contaminated domestic water, lead to disease through two principal transmission routes: either by drinking contaminated water, which leads to 'waterborne' diseases, or by a lack of sufficient water for washing and hygiene purposes, which leads to 'water-washed' diseases (10). Poor water quality continues to pose a major threat to human health (11), water pollution is a major cause of global concern as it leads to onset of numerous fatal diseases (12) which is responsible for the death of over 14,000 people every day (13).

Diarrheal disease alone amounts to an estimated $4.1 \%$ of the total Disability Adjusted Life Year (DALY) global burden of disease and is responsible for the deaths of 2 million people every year. It was estimated that $88 \%$ of that burden is attributable to unsafe water supply, sanitation, and hygiene is mostly concentrated on children in developing countries (14).

The waterborne illnesses, is the most widely associated with poor sanitation, inadequate hygiene, arise from ingestion of and contact with water contamination by human body secretions and/or animal faeces or urine infected with viruses or pathogenic bacteria, which are directly transmitted when the water is consumed or used for the preparation of food, in addition to deficiency of access to acceptable amounts of safe water (15). These illnesses include cholera, typhoid, cryptosporidiosis, amoebic and bacillary dysentery and other diarrheal diseases. 


\section{International Journal of Science and Research (IJSR) \\ ISSN (Online): 2319-7064 \\ Index Copernicus Value (2013): 6.14 | Impact Factor (2015): 6.391}

Globally, one in 10 deaths in children under the age of five years results from diarrhea (16). Statistics indicated that of the 0.71 million annual diarrheal deaths, $90 \%$ occur in children, mainly from developing countries (17). The global burden of disease and mortality rates could be reduced by about $9.1 \%$ and $6.3 \%$, respectively, if rapid success is attained in facilitating access to water, sanitation, and hygiene facilities $(18,19)$. Many studies reported that quality of water, sanitation systems and hygiene behavior are all connected to waterborne disease frequency in the communities $(2,3,20-27)$. For instance, promoting the simple and inexpensive hygiene procedure hand washing with soap (HWWS) has proved to be a remarkable effective way to prevent infections in the rural settings of developing countries $(28,29)$.

Gaza Strip's population suffers markedly from water-borne infections due to the lack of safe and sanitary water supply and disposal (30). According to the report prepared by Palestinian Environmental Friend Association 2013 (31) emphasizes that the health situation of most people in Al Shuka is not good and not accepted, where residents always complained from different communicable and skin diseases mainly among children; which may relate to the infectious diseases of the waste water bad situation. The main objective of this study is to identify the common water borne diseases among the community of Al Shuka area-Rafah and to detect the most age group affected by the identified common water borne diseases.

\section{Materials and Methods}

Study area: Al-Shuka area is small district in Rafah governorate located in the south-east of the Gaza Strip (Fig.1), with area about $22 \mathrm{~km}^{2}$; and 16,800 people distributed among 3000 houses. The most area is agricultural areas as documented by (31).

According to the report prepared by Palestinian Environmental Friend Association 2013; emphasizes that the health situation of most people in Al Shuka is not good and not accepted, where residents always complained from different communicable and skin diseases mainly among children; which may have related to the infectious diseases of the waste water bad situation. Al Shuka area suffers from the lack of the infrastructure, no paved streets, no sewage systems, no drainage networks and the municipality water networks cover only $60 \%$ of the whole area, with water sources from 3 municipality wells only located $10 \mathrm{~km}$ far from the area to the west. The quality of available water either from the municipality wells or the agricultural (private) wells is not suitable for the drinking purposes (31).

Citizens depend upon the cesspits to manage their wastewater, as the cesspits are not the suitable environmental solution for managing the wastewater. However, the bad economic situation and the weaknesses of the municipality infrastructures such as the sewers systems force people not to take care of these cesspits, which regular flooding forms waste water pools in the roads and yards. It is worth to mention that people always discharge the cesspits and the pools manually (18).

Study design: Cross-sectional study was conducted to identify the common water borne diseases among the community of $\mathrm{Al}$ Shuka area-Rafah governorate and to detect the most age group affected by the identified common water borne diseases. The researchers utilized and oral- administrated questionnaire for households.

A simple random sample technique was conducted to collect data. Selection of households was randomly from the targeted areas to ensure representative sampling and avoid any selection bias. Based on the number of completed questionnaires, the total number was 208 questionnaires with response rate bout $\approx 91.63 \%$.

Statistical analysis: The questionnaire was carefully checked to screen out any incompletely answered questions. Statistical Package of Social Science (SPSS) program was used for data entry and analysis. Statistical analysis was made including descriptive and inferential statistics. A statistical relationship between variables was assessed using different and relevant statistical test as needed, Logistic regression analysis was used to build a model to predict the values of the variable (the dependent variable) If the value of the variable or other variables (independent variables) are known.

Volume 5 Issue 7, July 2016 www.ijsr.net 


\section{International Journal of Science and Research (IJSR) \\ ISSN (Online): 2319-7064 \\ Index Copernicus Value (2013): 6.14 | Impact Factor (2015): 6.391}

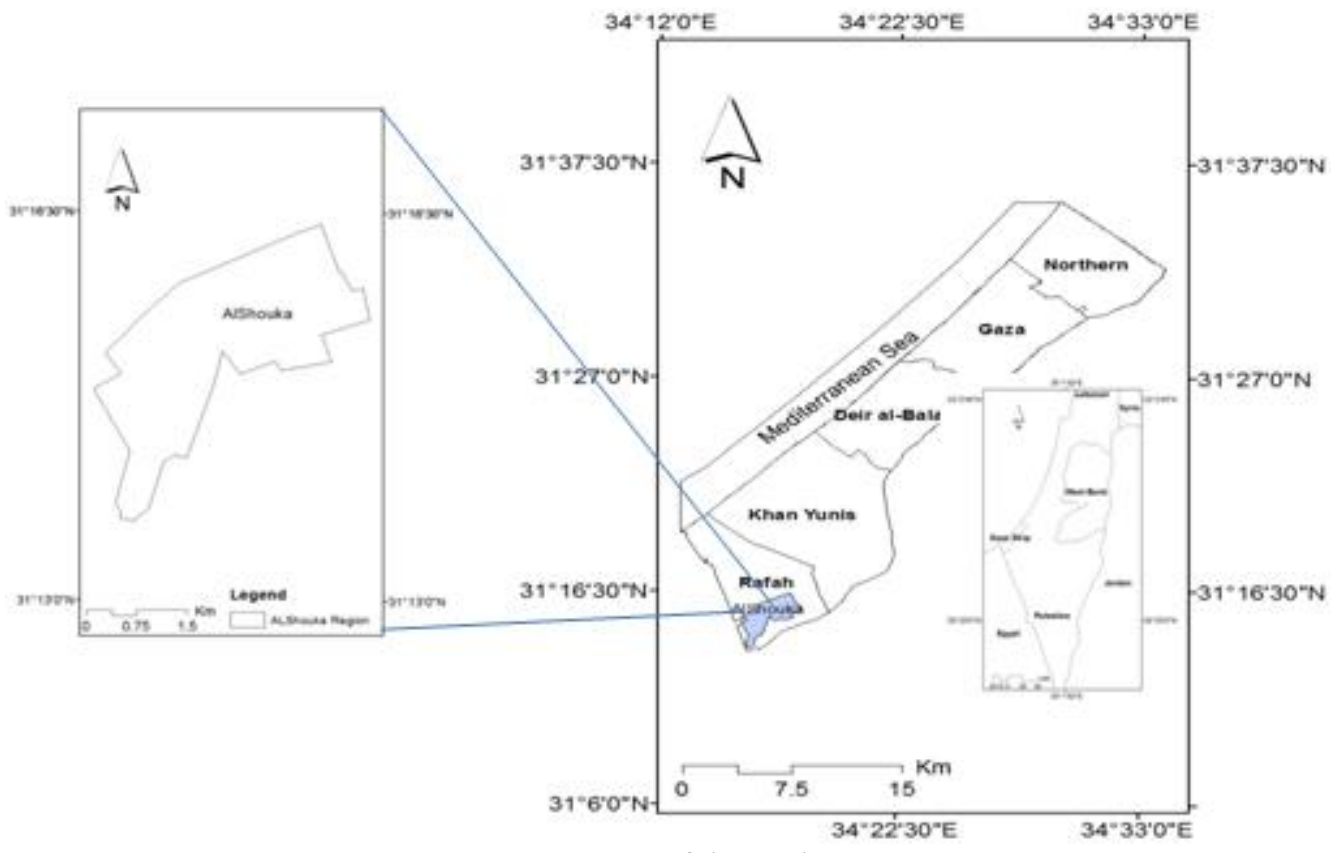

Figure 1: Map of the study area

\section{Results}

It is clear from Table 1 that there were about $13.0 \%$ of the study sample were illiterate, $25.0 \%$ preparatory, and $10.1 \%$ primary, $31.7 \%$ a secondary level and $20.2 \%$ a university level. Also, the distribution of the study sample due to job title emphasized that $29.8 \%$ of the study sample was employees, while $42.8 \%$ of them were unemployed. Moreover, most of the participants (46.2\%) monthly income was $\leq 500$ NIS $(<132 \$)$ whereas only $8.8 \%$ of the study sample their monthly income above 2500 NIS ( $\geq 658 \$$ ).

Table 1: Socio- demographic Characteristics

\begin{tabular}{|l|c|c|}
\hline \multicolumn{1}{|c|}{ Variable } & $\begin{array}{c}\text { Frequency } \\
(\mathrm{N}=208)\end{array}$ & $\begin{array}{c}\text { Percentage } \\
\%\end{array}$ \\
\hline \multicolumn{3}{|l|}{ Educational Background of the household } \\
\hline Illiterate & 27 & $13 \%$ \\
\hline Primary School & 21 & $10.1 \%$ \\
\hline
\end{tabular}

\begin{tabular}{|l|c|c|}
\hline Preparatory/elementary & 52 & $25 \%$ \\
\hline Secondary & 66 & $31.7 \%$ \\
\hline $\begin{array}{l}\text { University \& } \\
\text { Postgraduate }\end{array}$ & 42 & $20.2 \%$ \\
\hline Distribution of the study group according to their job \\
\hline Unemployed & 89 & $42.8 \%$ \\
\hline Employee & 62 & $29.8 \%$ \\
\hline Worker/ labor & 36 & $17.3 \%$ \\
\hline Farmer & 5 & $2.4 \%$ \\
\hline Doctor & 2 & $1 \%$ \\
\hline Housewife & 9 & $4.3 \%$ \\
\hline Teacher & 5 & $2.4 \%$ \\
\hline Average Monthly Income & 96 & $46.2 \%$ \\
\hline$\leq 132 \$$ & 50 & $24.2 \%$ \\
\hline$>132 \$-394.5 \$$ & 44 & $20.9 \%$ \\
\hline$>390 \$-657.5$ & 18 & $8.8 \%$ \\
\hline$>257.5 \$$ & $* *$ Hint: Local currency is NIS $=0.263 \$$ \\
\hline
\end{tabular}

Table 2: Common water borne diseases among Al Shuka community

\begin{tabular}{|c|c|c|c|c|c|c|c|}
\hline \multirow{2}{*}{\multicolumn{2}{|c|}{ Common water borne diseases }} & \multirow[b]{2}{*}{ Measures } & \multicolumn{5}{|c|}{ Age groups who affected by common water borne diseases } \\
\hline & & & Man & Woman & $\begin{array}{l}\text { Children } \\
\text { less than } 5 \\
\text { years }\end{array}$ & $\begin{array}{l}\text { Children } \\
\text { above } 5 \\
\text { years }\end{array}$ & $\begin{array}{l}\text { Total N= } \\
208\end{array}$ \\
\hline \multirow{2}{*}{\multicolumn{2}{|c|}{$\begin{array}{l}\text { Did any one of your family members have } \\
\text { had diarrhea diseases last two weeks? }\end{array}$}} & Number & 7 & 16 & 49 & 0 & 72 \\
\hline & & $\%$ & $9.7 \%$ & $22.2 \%$ & $68.1 \%$ & 0 & $34.6 \%$ \\
\hline \multirow{2}{*}{\multicolumn{2}{|c|}{$\begin{array}{c}\text { Did any one of your family members } \\
\text { affected by other diseases during the last } \\
\text { two weeks? }\end{array}$}} & \multicolumn{5}{|c|}{ Number } & 114 \\
\hline & & \multicolumn{5}{|c|}{$\%$} & $54.8 \%$ \\
\hline \multirow{6}{*}{$\begin{array}{c}\text { Categories of family } \\
\text { members who have had } \\
\text { affected by other diseases } \\
\text { during the last two weeks? }\end{array}$} & \multirow{2}{*}{$\begin{array}{l}\text { Dermal } \\
\text { diseases }\end{array}$} & Number & 12 & 43 & 21 & 13 & 89 \\
\hline & & $\%$ & $10.5 \%$ & $37.7 \%$ & $18.4 \%$ & $14.6 \%$ & $78 \%$ \\
\hline & \multirow[t]{2}{*}{ Colic diseases } & Number & 5 & 9 & 1 & 4 & 19 \\
\hline & & $\%$ & $26.3 \%$ & $47.4 \%$ & $5.3 \%$ & $21.1 \%$ & $9.1 \%$ \\
\hline & \multirow[t]{2}{*}{ Eye diseases } & Number & 9 & 11 & 22 & 23 & 65 \\
\hline & & $\%$ & $7.9 \%$ & $9.6 \%$ & $19.3 \%$ & $20.2 \%$ & $57 \%$ \\
\hline
\end{tabular}

Volume 5 Issue 7, July 2016 www.ijsr.net

Licensed Under Creative Commons Attribution CC BY 


\section{International Journal of Science and Research (IJSR) \\ ISSN (Online): 2319-7064 \\ Index Copernicus Value (2013): 6.14 | Impact Factor (2015): 6.391}

Table 2 shows that there were about $(n=72 ; 34.6 \%)$ of the study sample $(\mathrm{N}=208)$ have suffered from diarrhea during the last two weeks before filling the questionnaire. Regarding infection according to age, there were about $(\mathrm{n}=49 ; 68.1 \%)$ children less than 5 years from the study sample who suffered from diarrheal disease during last two weeks, then women with percentage of $(n=16 ; 22.2 \%)$, and about $(n=7 ; 9.7 \%)$ of them were men and no one of children more than 5 years were infected with diarrheal disease.

From the other hands, there were about $(\mathrm{n}=114 ; 54.8 \%)$ of the study sample $(\mathrm{N}=208)$ suffered from other waterborne disease which include dermal disease (Skin), colic disease (stomach pain) and eyes disease during last two weeks before filling the questionnaire. The statistical analysis results showed that out of $(n=114 ; 54.8 \%)$ of the study sample who suffered from other water borne diseases during last two weeks, about $(\mathrm{n}=89 ; 78 \%)$ were infected with dermal diseases.

Regarding infection according to age group; there were about $(n=43 ; 37.7 \%)$ women out of the study sample who suffered from dermal diseases during last two weeks, then children less than 5 years with percentage of $(n=21 ; 18.4 \%)$, and $(n=13$; $11.4 \%)$ were children more than 5 years' age and about $(\mathrm{n}=12$; $10.5 \%)$ were men. While about $(\mathrm{n}=19 ; 16.7 \%)$ were suffered from colic diseases, it found that according to the most age groups; the largest proportion of incidence was among women with $(\mathrm{n}=9 ; 7.9 \%)$, then among men with $(\mathrm{n}=5 ; 4.4 \%)$, and children above 5 years by $(\mathrm{n}=4 ; 3.5 \%)$ and finally children less than 5 years by $(\mathrm{n}=1 ; 0.9 \%)$, and it also found that, there were about $(\mathrm{n}=65,57 \%)$ were infected with eye diseases.

According to the age groups, the results demonstrated that were from children above 5 years with about $(\mathrm{n}=23 ; 20.2 \%)$, then children less than 5 years $(\mathrm{n}=22 ; 19.3 \%)$, then women $(\mathrm{n}=11 ; 9.6)$ and finally men $(\mathrm{n}=9 ; 7.9 \%)$. It's worth to mention that main health facilities which provide health care to the community of the study area are ministry of health $(\mathrm{MoH})$ and United Nations for refugees working affairs (UNRWA). Accordingly, authors obtained data from these facilities about the main common water borne disease at $\mathrm{Al}$ Shuka area to compare with the study results.

Table 3: Incidence of waterborne diseases in Al-Shuka area obtained from the records of Department of Epidemiology, UNRWA

\begin{tabular}{|c|c|c|c|c|c|}
\hline & $\begin{array}{c}\text { Acute bloody } \\
\text { diarrhea }\end{array}$ & $\begin{array}{c}\text { Acute watery } \\
\text { diarrhea }<5 \text { years }\end{array}$ & $\begin{array}{c}\text { Acute watery } \\
\text { diarrhea }>5 \text { years }\end{array}$ & $\begin{array}{c}\text { Viral } \\
\text { hepatitis A } \\
\end{array}$ & Typhoid \\
\hline $\begin{array}{c}\text { Year }(2010) \\
\text { Population }(11680) \\
\text { Cases No. } \\
\text { Infection rate } \%\end{array}$ & $\begin{array}{c}186 \\
1.59 \%\end{array}$ & $\begin{array}{c}522 \\
4.47 \%\end{array}$ & $\begin{array}{c}172 \\
1.47 \%\end{array}$ & $\begin{array}{l}0 \\
0\end{array}$ & $\begin{array}{l}0 \\
0\end{array}$ \\
\hline $\begin{array}{c}\text { Year (2011) } \\
\text { Population (12108) } \\
\text { Cases No. } \\
\text { Infection rate \% } \\
\end{array}$ & $\begin{array}{c}97 \\
0.80 \%\end{array}$ & $\begin{array}{c}460 \\
3.80 \%\end{array}$ & $\begin{array}{c}270 \\
2.23 \%\end{array}$ & $\begin{array}{c}8 \\
0.07 \%\end{array}$ & $\begin{array}{c}2 \\
0.02 \%\end{array}$ \\
\hline $\begin{array}{c}\text { Year }(2012) \\
\text { Population }(12552) \\
\text { Cases No. } \\
\text { Infection rate } \% \\
\end{array}$ & $\begin{array}{c}38 \\
0.30 \%\end{array}$ & $\begin{array}{c}407 \\
3.24 \%\end{array}$ & $\begin{array}{c}241 \\
1.92 \%\end{array}$ & $\begin{array}{c}5 \\
0.04 \%\end{array}$ & $\begin{array}{l}0 \\
0\end{array}$ \\
\hline $\begin{array}{c}\text { Year (2013) } \\
\text { Population (13010) } \\
\text { Cases No. } \\
\text { Infection rate \% }\end{array}$ & $\begin{array}{c}27 \\
0.21 \%\end{array}$ & $\begin{array}{c}199 \\
1.53 \%\end{array}$ & $\begin{array}{c}99 \\
0.76 \%\end{array}$ & $\begin{array}{c}11 \\
0.08 \%\end{array}$ & $\begin{array}{l}0 \\
0\end{array}$ \\
\hline $\begin{array}{c}\text { Year (2014) } \\
\text { Population (13840) } \\
\text { Cases No. } \\
\text { Infection rate \% }\end{array}$ & $\begin{array}{c}4 \\
0.03 \%\end{array}$ & $\begin{array}{c}144 \\
1.04 \%\end{array}$ & $\begin{array}{c}82 \\
0.59 \%\end{array}$ & $\begin{array}{c}10 \\
0.07 \%\end{array}$ & $\begin{array}{l}0 \\
0\end{array}$ \\
\hline
\end{tabular}

Volume 5 Issue 7, July 2016 www.ijsr.net 


\section{International Journal of Science and Research (IJSR) \\ ISSN (Online): 2319-7064 \\ Index Copernicus Value (2013): 6.14 | Impact Factor (2015): 6.391}

Table 4: Incidence of various waterborne diseases in Al-Shuka area as obtained from the records of Department of Epidemiology, $\mathrm{MoH}$

\begin{tabular}{|c|c|c|c|}
\hline & $\begin{array}{c}\text { Acute bloody } \\
\text { diarrhea }\end{array}$ & $\begin{array}{c}\text { Acute watery } \\
\text { diarrhea }<3 \text { years }\end{array}$ & $\begin{array}{c}\text { Acute watery } \\
\text { diarrhea }>3 \text { years }\end{array}$ \\
\hline Year (2010) & & & \\
\hline Pop. (10923) & & 0 & \\
\hline $\begin{array}{c}\text { Cases No. } \\
\text { Infection rate \% }\end{array}$ & $\begin{array}{c}22 \\
0.19 \%\end{array}$ & 0 & $0.78 \%$ \\
\hline Year (2011) & & & \\
\hline Pop. (11294) & 8 & 0 & 122 \\
\hline $\begin{array}{l}\text { Cases No. } \\
\text { Infection re }\end{array}$ & $0.07 \%$ & 0 & $1.01 \%$ \\
\hline Year (2012) & & & \\
\hline Pop. (11680) & & 0 & 123 \\
\hline $\begin{array}{c}\text { Cases No. } \\
\text { Infection rate \% }\end{array}$ & $0.04 \%$ & 0 & $0.98 \%$ \\
\hline Year (2013) & & & \\
\hline Pop. (12108) & 0 & 0 & \\
\hline Cases No. & 0 & 0 & $0.84 \%$ \\
\hline Year (2014) & & & \\
\hline Pop. (12552) & 5 & 0 & 213 \\
\hline Cases No. & $0.04 \%$ & 0 & $1.54 \%$ \\
\hline Infection rate $\%$ & & & \\
\hline
\end{tabular}

As emphasized in (table $3 \& 4$ ) showed that the results of the study questionnaires demonstrated the presence of common water borne and water related diseases in Al Shuka area which include: diarrhea, dermal, colic, and eyes diseases. As compared with All data collected from the records of Department of Epidemiology at UNRWA Ministry of Health $(\mathrm{MoH})$ and the UNRWA about the trend of waterborne diseases prevalence (2010-2014).

It was observed that more diseases registered in UNRWA are, acute bloody diarrhea, acute watery diarrhea $<5$ years, acute watery diarrhea $>5$ years, viral hepatitis $\mathrm{A}$ and Typhoid. Whereas the records of the Ministry of Health $(\mathrm{MoH})$ found that are, acute bloody diarrhea, acute watery diarrhea $<3$ years, and acute watery diarrhea $>3$ years over the years.

\section{Discussion}

Based on the study results, the most common water borne diseases in the area of Al Shuka are including: diarrheal, dermal, colic and eye diseases. These results are consistent with findings of different local studies which showed similar results in different areas in the Gaza Strip-Palestine $(2,3,20$, $21,25,26,32)$. As well, different findings worldwide revealed correlation between quality of water, sanitation systems and hygiene behavior with waterborne disease frequency in different countries $(22-24,27)$.

From the other hands, the results demonstrated that the most common age group who suffered from diarrheal diseases among the infected people was children less than 5 years $(n=49 ; 68 \%)$. As compared with All data collected from the records of Ministry of Health and the UNRWA health providers in Gaza Strip -Palestine about the trend of waterborne diseases prevalence from period between (20102014), it was observed that more diseases registered in
UNRWA are, acute bloody diarrhea, acute watery diarrhea $<5$ years, acute watery diarrhea $>5$ years, viral hepatitis $A$ and Typhoid. In addition, these results agreed with findings of (21, $33,34)$.

The risk factor associated with waterborne diseases is defined as including multiple factors, namely the ingestion of unsafe water, lack of water linked to inadequate hygiene, poor personal and domestic hygiene, contact with unsafe water, (35). Regarding infection according to age group $(n=43$; $37.7 \%$ ) of the study sample were among women who suffered from dermal diseases. Also the largest proportion of incidence of colic, was among women with $(\mathrm{n}=9 ; 7.9 \%)$. This results explained by women who stated during the focus groups discussion that they were responsible about emptying cesspit and septic tanks at their houses by their hand which resulted in direct contact with raw wastewater and infected them with pathogens.

\section{Conclusion}

In this study found to the most common water borne diseases in the area of $\mathrm{Al}$ Shuka are including: diarrheal, dermal, colic and eye diseases. Also, the results demonstrated that the most common age group who suffered from diarrheal diseases among the infected people was children less than 5 years.

Regarding infection according to age group of the study sample were among women who suffered from dermal and colic diseases. As well as, the most age groups who were infected with eye diseases were from children above 5 years. Accordingly, safe and clean water supply should be ensured in order to cover people needs and protect their health. Also, conducting public awareness campaigns and behaviour change towards improving the surrounded environment, personal

Volume 5 Issue 7, July 2016 www.ijsr.net 


\section{International Journal of Science and Research (IJSR) \\ ISSN (Online): 2319-7064 \\ Index Copernicus Value (2013): 6.14 | Impact Factor (2015): 6.391}

hygiene, cleanliness and sanitary programs should be ensured mainly in rural and vulnerable area of the Gaza Strip.

\section{Acknowledgments}

Authors would like to acknowledge the Middle East Desalination Research Center (MEDRC) for supporting this research.

\section{References}

[1] Abbas M, Barbieri M, Battistel M, Brattini G, Garone A Parisse B. Water quality in the Gaza Strip: The present Scenario. Journal of Water Resource and Protection (2013) 5: 54-63.

[2] Abu Amr S, Yassin M. Microbial contamination of the drinking water distribution system and its impact on human health in Khan Younis Governorate, Gaza Strip: 7 years of monitoring (2000-2006). Public Health (2008) 122(11):1275-83.

[3] Abu-Hejleh B. An Epidemiological Study on the Effect of Water on Health in Tubas District. Master Thesis, Faculty of Graduate Studies, An-Najah National University, Nablus, West Bank, Palestine (2004).

[4] Al -Najar H. The integration of FAO-Crop wet model and GIS techniques for estimating irrigation water requirement and its application in the Gaza Strip. Natural Resources (2011) 2:146- 154.

[5] El-Nahhal Y. Harrarah, S. Contamination of groundwater and associated disease: case study from Khan Younis governorate, Gaza, PNA. Journal of Environment and Earth Science (2013) 3(5): 147-154.

[6] Nettnin S. Why a water crisis exists in Gaza. Palestine Media Center (PMC) (2005). Retrieved from http://www.palestine-pmc.com/details.as;?cat=3\&id=755.

[7] United Nations Children's Fund (UNICEF). Children in an urban world, report on the state of the world's children (2012). www.unicf.org/sowc2012.

[8] El-Tabash M. Investigation of Drinking Water Quality at Kindergartens in the Gaza Strip. Master Thesis in water and environmental science, Institute of Water and Environment (IWE), Al Azhar University-Gaza, Palestine (2014).

[9] Gruppo di Volontariato Civile (GVC) and Palestinian Hydrology Group (PHG). Water quality monitoring campaigns middle area of the Gaza Strip. Drinking water quality monitoring campaigns narrative report, in coordination with Costal Municipalities Water Utility (CMWU) and Palestinian Water Authority (PWA) October (2009).

[10] Montgomery M, Elimelch, M. Water and sanitation in developing countries: including health in the equation. Environmental Science \& Technology (2007) 17-24.

[11] World Health Organization. Practical Guidance for Assessment of Disease Burden at National and Local Levels (2013). Available: http://www.who.int/quantifying _ ehimpacts/national/en/index.html (accessed on 7th, March 2015).

[12]Daniels B. Policy Forum: Funding of public and private schools in Australia Independent schools and equity: challenging conventional wisdom. Australian Economic Review (2011) 44(3):330-7.

[13] Cheng E, Vaisica JA, Ou J, Baryshnikova A, Lu Y, Roth FP, Brown GW. Genome rearrangements caused by depletion of essential DNA replication proteins in Saccharomyces cerevisiae. Genetics (2012)192(1):147-60.

[14] World Health Organization. Report on World malaria. World Health Organization: Geneva (2014).

[15] World Health Organization (WHO). Guidelines for drinking water quality. 3rd edition, (1), Geneva (2008).

[16] Chola L, Michalow J, Tugendhaft A, Hofman K. Reducing diarrhoea deaths in South Africa: costs and effects of scaling up essential interventions to prevent and treat diarrhoea in under-five children. BMC Public Health (2015) 15:394 doi:10.1186/s12889-015-1689-2.

[17] Kattula D, Sarkar R, Ajjampur SSR, Minz S, Levecke B, Muliyil J, Kang G.. Prevalence and risk factors for soil transmitted helminth infection among school children in south India. Indian Journal of Medical Research (2014) 139: 76-82.

[18] Joshi A, Amadi C. Impact of Water, Sanitation, and Hygiene Interventions on Improving Health Outcomes among School Children. Journal of Environmental and Public Health (2013):10.

[19] Prüss-Üstün A, Bos R, Gore F, Bartram J. Safer water, better health: costs, benefits and sustainability of interventions to protect and promote health. World Health Organization, Geneva, (2008).

[20] Al Zarqa M. Water pollution in central and northern governorates of Gaza Strip, and the effects of using such water on health. (Unpublished Master Thesis). Islamic University - Gaza / Faculty of Arts - Department of Geography (2010).

[21] The United Nations for Children's Fund (UNICEF) and Palestinian Hydrology Group (PHG). Water, Sanitation and Hygiene Household Survey Gaza, (2010).

[22] Azizullah A, Khattak M, Richter P, Häder D. Water pollution in Pakistan and its impact on public health - A review. Environ. Int (2011) 37: 479-497.

[23] Aryal K, Joshi H, Dhimal M, Singh S, Dhimal B, Dhakal P, Bhusal C. Environmental burden of diarrhoeal diseases due to unsafe water supply and poor sanitation coverage in Nepal. Nepal Health Research Council, Kathmandu (2012) 10 (21): 125-29.

[24] Maxwell N, Scourfield, J, Holland S, Featherstone B, Jacquie L. The benefits and challenges of training child protection social workers in father engagement. Child Abuse Review (2012) 21 (4): 299-310.

[25] El-Nahhal Y, Harrarah S. Contamination of groundwater and associated disease: case study from Khan Younis governorate, Gaza, PNA. Journal of Environment and Earth Science (2013) 3(5):147-154.

[26] Taleb K. Characterization of the potential waterborne diseases in Wadi Gaza - Gaza Strip. (Unpublished Master Thesis). Islamic University- Gaza/ Faculty of 


\section{International Journal of Science and Research (IJSR) \\ ISSN (Online): 2319-7064}

Index Copernicus Value (2013): 6.14 | Impact Factor (2015): 6.391

Engineering-Civil Engineering Department -Water Resources Engineering (2014).

[27] Pathak H. Effect of water borne diseases on Indian economy: a cost- benefit analysis. analele universităţii din oradea-seria geografie (2015) 1:74-78. ISSN 1454-2749, E-ISSN 2065-1619 article no. 251108-678.

[28] Cairncross S, Hunt C, Boisson S, Bostoen K, Curtis V, Fung ICH. Water, sanitation and hygiene for the prevention of diarrhoea. Int J Epidemiol (2010b)39 (suppl 1), I:193-I205.

[29] Ejemot R, Ehiri J, Meremikwu M, Critchley J. Hand washing for preventing diarrhoea. Cochrane Database Syst Rev. (2008) 23(1):CD004265. doi: 10.1002/14651858.CD004265.pub2.

[30] Sarsour A, Salem A. Water scarcity and trachoma prevalence in Gaza Strip, Palestine: possibilities and precautions according to WHO SAFE strategy for trachoma control. International Journal of Pharmacy Teaching \& Practices (2013)4(2): 6 22- 630.

[31] Alnahhal S, Aljojo F. Power analysis report: Al Shuka area -Rafah Governorate. Palestinian Environmental Friends Association, (2013).

[32] Yassin M, Abu Amr S, Al-Najar H. Assessment of microbiological water quality and its relation to human health in Gaza Governorate, Gaza Strip. Public Health (2006) (120): 1177-1187.

[33] Palestinian Water Authority (PWA). Assessment of water resources in Rafah Governorate-Gaza Strip, 2014. Technical report prepared by Water Resources General Directorate (2015).

[34] UNICEF and World Health Organization. Progress on drinking water and sanitation: 2012 Update. Report of WHO/UNICEF Joint Monitoring Programme for Water Supply and Sanitation. ISBN: 978-92-806-4632-0 (NLM classification: WA 670) ISBN: 972-924-1503297 Printed in the United States of America (2012).

[35] Green S, Small J, Casman A. Determinants of national diarrhoeal disease burden. Environmental Science and Technology (2009) 43 (4):123-31.

\section{Author Profile}

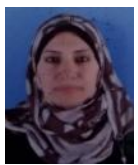

Mrs. Ghada Al Khateeb received her first degree from Islamic University Gaza in 1999 awarded with Bachelor of Environment and earth sciences. She is doing a Master Degree in Water and Environment at institute of water and environment (IWE) -Al Azhar University, Gaza- Palestine. She works as environmental health Guidance (EHG) in Environmental Awareness Department; Holest Cultural Center at Gaza Municipality, and has wide experience in environmental health field. Also, she is member at Arab Union for Specialized womanEnvironment sector.

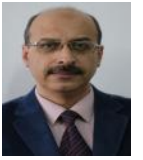

Associated Professor Dr Mazen Hamada received his doctorate from University of Graz in Austria in 2002 with major in Environmental Analytical Chemistry. Currently Dr Mazen serves in Academic appointment as lecturer at the department of Chemistry and at the Master Program of Water and Environment- Al Azhar University, Gaza Palestine. Also, Dr Mazen works as President of the Board of the University Presidency. He has published several refereed articles in professional peer review journals in the field of water, soil and environmental pollution.

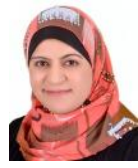

Assistant Professor Dr Amal Khalil Sarsour received her doctorate from Universiti Sains Malaysia in 2012 with major in Environmental Management. Currently Dr Amal serves in Academic appointment as lecturer at Master Program of Water and Environment- Al Azhar University, Gaza Palestine. Also, supervisor for MSc students in Al Quds University, Palestine and Al Azhar University. She works consultant and training specialist with different national and international organization in the field of environmental health and conducting awareness programs among the whole community levels in. She has published several refereed articles in professional peer review journals in the field of environmental health and environmental management.

Volume 5 Issue 7, July 2016 www.ijsr.net 